\title{
DRIVERS OF EARLY WASTE DISPOSAL ACTIVITIES IN ENGLAND
}

\author{
SITI KHADIJAH ABD. GANI ${ }^{1,2}$ \\ ${ }^{1}$ Faculty of Engineering and the Environment, University of Southampton, UK \\ ${ }^{2}$ Public Service Department, Putrajaya, Malaysia
}

\begin{abstract}
This paper aimed to identify drivers that triggered early waste disposal activities in England. Various publications were used to identify historical events related to waste disposal activity, recorded from 1297 to 1948 . A synthesis matrix is used to relate various historical events to waste activity. The historical events are then illustrated in a diagram, in order to identify the drivers. This study found that disasters in the form of fire, pandemic diseases and wars, as well as the Industrial Revolution, directly triggered early disposal activities in England (in particular in London).

Keywords: drivers, early disposal sites, England, historical events, solid waste management, United Kingdom, waste disposal activity.
\end{abstract}

\section{INTRODUCTION}

As a developed country, England has a long history of waste disposal and landfill creation. Waste disposal was a common practice for households, on a small scale, as early as 1297 [1]. During the Industrial Revolution, disposal sites were needed not only for households, but also industries to get rid of their waste [2], [3]. In those days, disposal sites varied from being open areas, old quarries, closed coal mines, clay-pits, or nearby water sources such as rivers or sea dumping [4]. It was seen as convenient to use quarries, coal mines and clay-pits; as gaping holes could be filled [5]. Disposal was a common practice, as it was cheap and there were available spaces to use as disposal sites.

Exploring various historical events and the identification of drivers that were directly related to the use of early disposal sites in England is beneficial for other countries in general, in particular for developing countries. Most developing countries are dealing with inefficient waste management, and would prefer open dumping or landfill use as final waste destination [6], [7]. Therefore, this paper aimed to:

1. Explore various historical events recorded in England that may directly be related to disposal activity;

2. Develop a synthesis matrix based on various events; and

3. Identify drivers that triggered early disposal activity. The findings from this paper also provide a foundation for further exploration of various initiatives that influenced waste disposal and landfill characteristics in England.

\section{METHODOLOGY}

Observing information about the past in reverse chronology, it is clear that England had regulated all their disposal and landfill sites to become fully engineered sanitary landfills (traditionally known as control tipping), since the enforcement of the Control of Pollution Act (1974). Two legal bindings, known as the Public Health Act (1936) and the Town and Country Planning Act (1947) had stated that the local authority must issue the planning permission for land development, including the disposal and landfill sites.

The earliest commission declaration related to waste management in England was in 1297, where it was stated that every household in London must maintain the cleanliness of their 
pavement [1]. There is no evidence nor publication related to disposal activity in England that is earlier than 1297. Thus, the year 1297 will be chosen as a starting point for this paper. As for the end point, the year 1948 will be chosen, as this is the year where the Environment Agency (EA) had started documenting all historic landfill datasets throughout England. This dataset was a compilation of all localities of closed disposal and landfill sites, starting from 1900 until 2016; however, there are more than 8,000 sites that were recorded without any details on the year of starting operation, nor year of closure. Hence, the timeline proposed in this paper goes from 1297 until 1948.

Various historical events that are related to waste management were gathered from the literature and analysed. A synthesis matrix will be used to explore each events' connectivity with disposal activity [8]. Each event is clustered, based on different waste management events. The locality of each event was identified either by the event having happened throughout England, or by researching a selected area, such as the urban areas or specifically, London. Based on the waste management events identified, connectivity of each event was made in a diagram, in order to identify the drivers that triggered early disposal activity.

\section{RESULTS AND DISCUSSION}

Historical events that occurred in England were gathered and a synthesis matrix was used to highlight the historical events' connectivity to waste activity (Table 1). The synthesis matrix developed was a good tool to help link unrelated events.

Death and disasters were some of the drivers that triggered the need for early disposal sites. The cities were in a rather unhygienic state because of lack of waste management, causing vectors like rats and insects to breed. Various bacterial infectious diseases including plague, cholera, dysentery, tuberculosis and influenza are closely related to bad hygiene, and had negative impacts to the English population. The plague and cholera had killed thousands of people in London [9]-[11]. The King's order to prevent plague in 1666 had stated that houses with an infected patient must be quarantined while the patient is treated, and if death occurs, the houses were to be disposed of or burnt [12].

Political instability had caused the Wars of the Roses and the English Civil Wars, and these killed hundreds of thousands of people [13]. After each occasion of disaster and war, the area was covered with damage, broken parts of buildings and furniture, etc. Bigger events produced more damage, and the quantity and composition of these wastes meant that they were unsuitable to be buried in every household's backyard heap. Therefore, it is assumed that more areas were needed, to be able to dispose of the waste.

In order to illustrate this assumption, waste activities that were gathered based on the historical events that occurred in the London area (Table 1) will only be used to view their connectivity with each other (Fig. 1). Arrows are used to connect one event to another. An event could be connected to one or more events.

One of many explanations from Fig. 1 is that disasters (disease, fire and war) created additional homeless and poor people, on top of the existing homeless and poor before the disasters happened. As their belongings and home were totally lost or damaged due to fire and/or war, they had no choice but to become homeless after their family died due to disaster or diseases, so they had to move out of their contaminated property.

Homeless people lived an unhygienic lifestyle, that either used shared cess-pools or sent their sewage and waste into the river. Although richer people had appointed contractors to handle their sewage and waste, the practice of discharging it to the river was common. This behaviour created sanitation problems. This issue was observed by Sir Edwin Chadwick in his report; this translated eventually to the Public Health Act (1848), which stated that the 
Table 1: Synthesis matrix of historical events related to early disposal activity in England.

\begin{tabular}{|c|c|c|}
\hline Waste activity & Historical events' connectivity to waste & Source \\
\hline $\begin{array}{l}\text { Enforcement of } \\
\text { household cleanliness } \\
\text { (1297) }\end{array}$ & $\begin{array}{l}\text { London population were mostly farmers and lived } \\
\text { with livestock. Each house had a small disposal area } \\
\text { in their back yard. In 1297, a regulation was enforced } \\
\text { that every household must ensure their surrounding's } \\
\text { cleanliness. }\end{array}$ & $\begin{array}{l}{[1],} \\
{[14]}\end{array}$ \\
\hline $\begin{array}{l}\text { Unhygienic lifestyle } \\
(1315-1322)\end{array}$ & $\begin{array}{l}\text { The Great Famine had caused inadequate food, } \\
\text { massive livestock carcass problems, homelessness } \\
\text { and starvation. }\end{array}$ & $\begin{array}{l}{[11]} \\
{[15]}\end{array}$ \\
\hline $\begin{array}{l}\text { Unhygienic lifestyle } \\
\text { (1348) }\end{array}$ & $\begin{array}{l}\text { Livestock and dogs were wandering outside of the } \\
\text { house area. Therefore, droppings and carcasses were } \\
\text { massive sources of nearby waste. This perhaps } \\
\text { triggered the Black Death (Plague), which had killed } \\
\text { the population by } 33 \% \text { (England) and } 15 \% \text { (London). } \\
\text { People were exposed to infectious disease and } \\
\text { starvation. }\end{array}$ & $\begin{array}{l}{[1],} \\
{[11]}\end{array}$ \\
\hline $\begin{array}{l}\text { Weekly waste } \\
\text { collection (1354) }\end{array}$ & $\begin{array}{l}\text { Waste was kept in the house compound until the } \\
\text { weekly collection day, starting in } 1354 \text { in London. } \\
\text { Charges applied to those caught leaving their waste } \\
\text { outside the house area. }\end{array}$ & {$[1]$} \\
\hline $\begin{array}{l}\text { Traditional waste } \\
\text { transportation }(1387- \\
1894)\end{array}$ & $\begin{array}{l}\text { Horses were the main transport used in London, since } \\
\text { 1387. Horses were used as public transportation, as } \\
\text { well as to remove waste from the city over to the } \\
\text { river or marshes. The Great Horse Manure Crisis } \\
\text { (1894) was recorded for London. There were more } \\
\text { than 50,000 used in transport and this had caused } \\
\text { massive amounts of horse droppings and carcasses. } \\
\text { This unhealthy environment had exposed the people } \\
\text { to disease. }\end{array}$ & [1] \\
\hline $\begin{array}{l}\text { Massive waste } \\
(1455-1651)\end{array}$ & $\begin{array}{l}\text { War of Roses and Civil Wars (1455-1651) had } \\
\text { caused political instability, inadequate food and } \\
\text { killed } 100,000 \text { people. Waste was produced after the } \\
\text { wars. }\end{array}$ & $\begin{array}{l}{[10]} \\
{[11]}\end{array}$ \\
\hline $\begin{array}{l}\text { Unhygienic lifestyle } \\
(1665)\end{array}$ & $\begin{array}{l}\text { In London, the Great Plague (1665) killed over } \\
7,000 / \text { week. }\end{array}$ & [12] \\
\hline Massive waste (1666) & $\begin{array}{l}\text { The Great Fire of London (1666) had burnt more than } \\
13,000 \text { wooden houses and their furniture. Thus, } \\
\text { there were } 100,000 \text { people who became homeless and } \\
\text { waste was left. }\end{array}$ & $\begin{array}{l}{[9],} \\
{[16]}\end{array}$ \\
\hline $\begin{array}{l}\text { Disposal site (1715- } \\
1815)\end{array}$ & $\begin{array}{l}\text { One early disposal area is located nearby Grays Inn } \\
\text { Lane, London }(1715-1815) \text {. It was in use for } 100 \\
\text { years. Later in } 1815 \text {, the dust was collected for brick- } \\
\text { making. }\end{array}$ & {$[1]$} \\
\hline
\end{tabular}


Table 1: Continued.

\begin{tabular}{|c|c|c|}
\hline Waste activity & Historical events' connectivity to waste & Source \\
\hline $\begin{array}{l}\text { London Waste } \\
\text { Strategy by Morris } \\
(1751)\end{array}$ & $\begin{array}{l}\text { The Corbyn Morris strategy (1751) proposed waste } \\
\text { collection and its disposal outside of London, as well } \\
\text { as usage of a land improver (fertilizer) made out of } \\
\text { food waste. This triggered other private initiatives, } \\
\text { including the jobs of night-man waste carter and } \\
\text { dust-man. }\end{array}$ & {$[1],[3]$} \\
\hline $\begin{array}{l}\text { Organic waste to } \\
\text { complex waste } \\
(1760-1840) \\
\end{array}$ & $\begin{array}{l}\text { The English Industrial Revolution started, opening up } \\
\text { the early modern economy, transportation and mass } \\
\text { production. }\end{array}$ & {$[17]$} \\
\hline $\begin{array}{l}\text { Dust-yard (1800- } \\
1900)\end{array}$ & $\begin{array}{l}\text { Collection of residue from household ash for brick } \\
\text { making and soil conditioner at the London dust-yard } \\
(1800-1900) \text {. This activity is the closest to traditional } \\
\text { recycling. }\end{array}$ & $\begin{array}{c}{[1],[3]} \\
{[18]}\end{array}$ \\
\hline $\begin{array}{l}\text { Unhygienic lifestyle } \\
(1848-1915)\end{array}$ & $\begin{array}{l}\text { Records of different infectious diseases, starting with } \\
\text { cholera (1848-1858) that killed 250,000 Londoners; } \\
\text { tuberculosis (1880) that killed 80,000 English people; } \\
\text { unknown infectious disease (1911-1915) that killed } \\
50 \% \text { of children between 5-9 years old; and in WWI } \\
(1914-1918) \text {, England faced an influenza outbreak. }\end{array}$ & $\begin{array}{l}{[13],} \\
{[19]}\end{array}$ \\
\hline $\begin{array}{l}\text { Public Health Act } \\
(1848,1875)\end{array}$ & $\begin{array}{l}\text { This Act was developed by Sir Edwin Chadwick in } \\
\text { 1848, after he wrote about unsanitary conditions } \\
\text { among poor people in London. These people used } \\
\text { shared cess-pools and practiced river dumping. This } \\
\text { Act was later reviewed (1875): waste collection was } \\
\text { done by the local authority. }\end{array}$ & $\begin{array}{l}{[20],} \\
{[21]}\end{array}$ \\
\hline $\begin{array}{l}\text { John Snow } \\
\text { investigation (1854) }\end{array}$ & $\begin{array}{l}\text { John Snow discovered that cholera outbreak was } \\
\text { waterborne in } 1854 \text {. London drinking wells were } \\
\text { contaminated due to cess-pools being developed } \\
\text { nearby. }\end{array}$ & $\begin{array}{l}{[22],} \\
{[19]}\end{array}$ \\
\hline $\begin{array}{l}\text { Modern sewage } \\
\text { technology }(1875)\end{array}$ & $\begin{array}{l}\text { The current sewage system practices of shared cess- } \\
\text { pools and river dumping had led to the Great Stink of } \\
\text { London. Later, rich people developed the private } \\
\text { indoor toilet. Outbreaks and the poor sewage system } \\
\text { prompted Parliament to take action: by } 1875 \text {, London } \\
\text { had completed its underground drainage and sewage } \\
\text { system. }\end{array}$ & $\begin{array}{l}{[20],} \\
{[23]} \\
{[22]} \\
{[21]}\end{array}$ \\
\hline Destructor (1876) & $\begin{array}{l}\text { The first destructor was built in Nottingham (1876) } \\
\text { and replicated throughout England. Destructors } \\
\text { burned waste and generated electricity (then the } \\
\text { smoke issue was raised). }\end{array}$ & {$[5]$} \\
\hline Land disposal (1876) & $\begin{array}{l}\text { The River Pollution Act (1876) had banned river } \\
\text { dumping; thus, only land disposal was allowed. }\end{array}$ & {$[24]$} \\
\hline $\begin{array}{l}\text { Local Government } \\
\text { Act (1894) }\end{array}$ & $\begin{array}{l}\text { Local Government Act (1894) stated that local } \\
\text { authorities are responsible for waste collection, } \\
\text { disposal and sewage. }\end{array}$ & {$[3]$} \\
\hline
\end{tabular}


Table 1: Continued.

\begin{tabular}{llc}
\hline Waste activity & Historical events' connectivity to waste & Source \\
\hline $\begin{array}{l}\text { Modern waste } \\
\text { transport (1899) }\end{array}$ & $\begin{array}{l}\text { Westminster City Council (1899) used a steam } \\
\text { engine vehicle for waste collection. }\end{array}$ & {$[3]$} \\
\hline $\begin{array}{l}\text { Massive waste } \\
(1914-1918)\end{array}$ & $\begin{array}{l}\text { WWI (1914-1918) had killed more than 8,000 } \\
\text { civilians and caused building destruction due to } \\
\text { bombing. }\end{array}$ & $\begin{array}{c}{[11],} \\
{[13]}\end{array}$ \\
\hline Soil or ash cover used & $\begin{array}{l}\text { Ministry of Health (1922) circular: all local } \\
\text { authorities were to implement minimum standards at } \\
\text { disposal sites, to use soil or ashes as final capping. }\end{array}$ & {$[25]$} \\
$(1922)$ & $\begin{array}{l}\text { By 1934, most closed sites used this approach for } \\
\text { vegetation recovery. }\end{array}$ & \\
\hline & $\begin{array}{l}\text { Dataset created in 1948, maintained until now by the } \\
\text { Environment Agency (and its predecessors). It was } \\
\text { created to assist local planning authorities by }\end{array}$ & \\
providing reliable information about closed landfills. & {$[26]$} \\
Dataset (1948) & $\begin{array}{l}\text { There were 19,705 disposal/landfill sites throughout } \\
\text { England, 1900-2016. }\end{array}$ & \\
& & \\
\hline
\end{tabular}

local authority holds the responsibility for household waste collection. The situation of shared cess-pools and sending sewage to the river highlighted the improper sewage system. The lack of a sewage system caused cholera and the Great Stink of London, which killed people. John Snow's discovery that cholera was waterborne strengthened the theory that poor sewage and a poor drainage system were contributing to an alarming public health issue. Therefore, the existing Public Health Act of 1848 was revised in 1875. The new revision addressed the waste issue, stating that the local authorities are in charge of sanitary, waste and drainage issues. The local authority could impose a penalty on housing developments without drainage systems and toilets. They also were to provide waste collection service to the area.

The practice of sending waste and sewage to the river was addressed later by the Government, with the enforcement of the River Pollution Act in 1876. This Act indirectly addressed the need for disposal sites on land, rather than the existing practice of river dumping. The legal action translated into the Public Health Act (1875) and the River Pollution Act (1876) clearly indicated that serious actions were taken in order to address the public health issues.

The destructors (traditional incinerations) were used as an alternative to manage waste. Cremation technology was modified, to create incinerators for wastes [5]. The first incinerator was designed and patented by A. Fryer and installed in Nottingham, England in 1876 [5], [27]. This technology was the main source for electricity supply in various urban areas [25]. Research into incineration helped the development of the high-temperature incinerator, which was installed and adopted throughout Europe [28].

The development of incinerators reduced the amount of waste sent to disposal sites; however, the cost to develop a plant was high. Edinburgh constructed a ten-cell destructor in 1893 with a total cost of $£ 16,000$ [27], approximately $£ 500,000$ in today's money. Ashes from the incineration were used as an alternative construction material. Electricity supply from incineration and the usage of incinerator ashes as alternative construction material highlight that waste-to-energy activities and resource recovery had already begun being practiced in the UK in the 1800 s. 


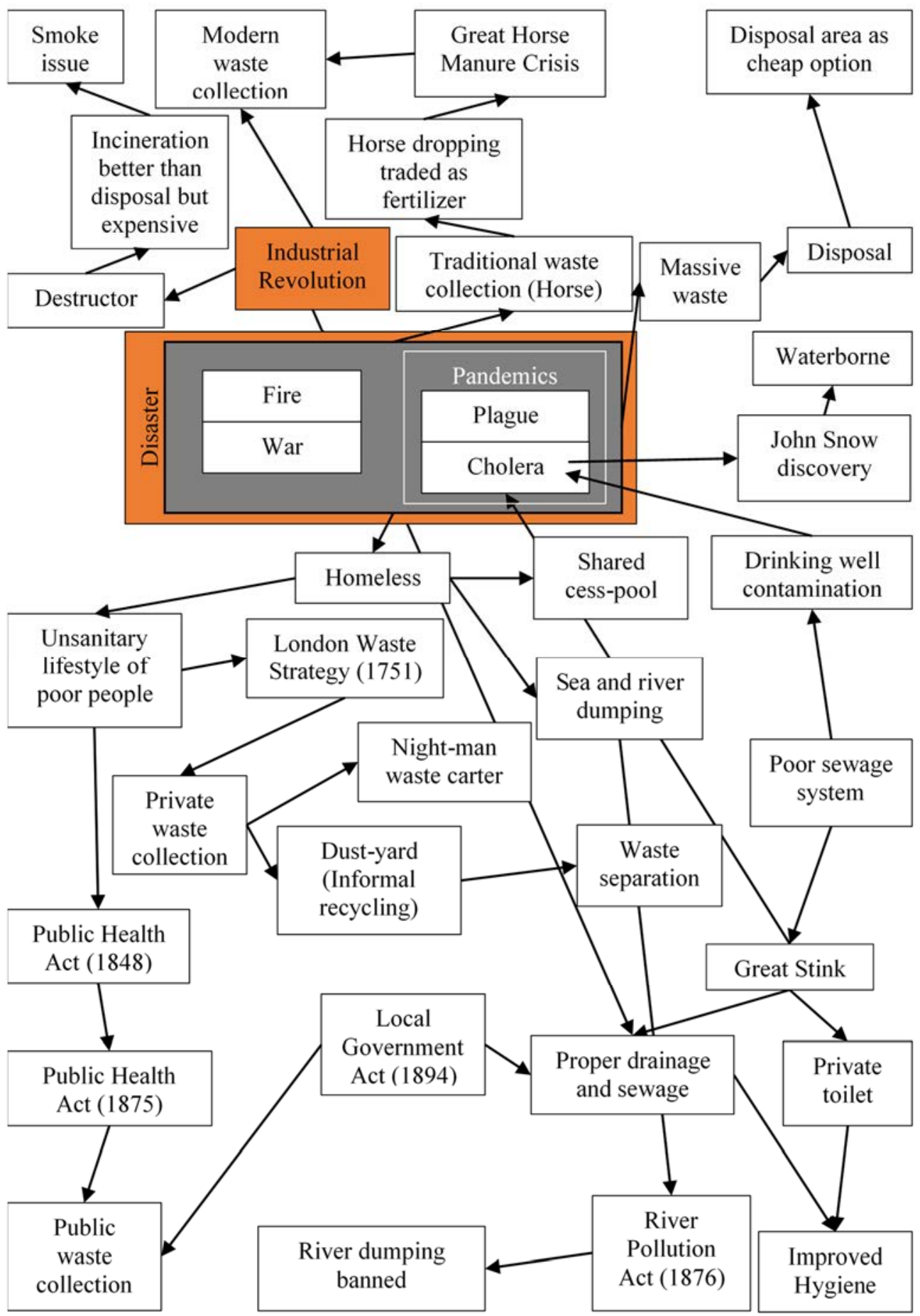

Figure 1: Connectivity between historical events that trigger the need for early disposal sites in London. 


\section{CONCLUSIONS}

It is clear that between 1297-1948, early waste management systems in England (particularly London) were developed to ensure there would be less threat to the people that might cause death. The role of the destructor in reducing the amount of waste being disposed of started long ago in England. Another role of destructors is to utilise waste and convert it to energy (electricity). Even though the medical aspects were rather basic compared to modern technology, various approaches were used, and the success stories were shared among cities.

It is clear that disaster in the form of pandemic diseases, fire and war triggered the early need for waste disposal sites. Whenever disaster occurred, various actions were taken by the people to adjust and adapt their lifestyle to the surrounding environment. The process of adjusting and adapting may or may not generate waste; therefore, a specific authority was needed in order to enforce the actions that might create a solution to the negative impact of the existing situation and move towards a positive impact.

The Industrial Revolution also triggered the need for early disposal sites. After this Revolution, there was a major shift from traditional production to advanced production of various products in large volumes. This Revolution also broadened technology enhancements for modern transport and other alternatives in waste management, such as incinerators.

\section{ACKNOWLEDGEMENTS}

I gratefully acknowledge that research for this article was generously funded by the Malaysian Government. I would like to thank Kohei Watanabe (professor from Teikyo University, Japan), who is a visiting researcher at the Faculty of Engineering and the Environment, University of Southampton, UK, for his suggestions and guidance.

\section{REFERENCES}

[1] Wilson, D.G., A brief history of solid-waste management. Int. J. Environ. Stud., 9(2), pp. 123-129, 1976. www.tandfonline.com/doi/abs/10.1080/00207237608737618. Accessed on: 9 Jun. 2016.

[2] King, W., How high is too high ? Disposing of dung in seventeenth-century prescot. Sixth Century J., 23(3), pp. 443-457, 1992. www.jstor.org/stable/pdf/2542488.pdf. Accessed on: 1 Mar. 2017.

[3] Herbert, L., Centenary history of waste and waste managers in London and Southeast England. The Chartered Institution of Waste Management, pp. 1-52, 2007. //C:/Users/skag1g15/Downloads/ 100_yrs_London_and_SE_centre.pdf. Accessed on: 11 May 2016.

[4] Jin, D., Multimedia waste disposal optimization under uncertainty with an ocean option. Mar. Resour. Econ., 9, pp. 119-139, 1994. https://core.ac.uk/download/pdf/ 6942182.pdf. Accessed 9 Jul. 2016.

[5] Clark, J.F.M., "The incineration of refuse is beautiful": Torquay and the introduction of municipal refuse destructors. Urban Hist., 34(2), pp. 255-277, 2007. https://research-repository.st.andrews.ac.uk/bitstream/handle/10023/1492/Clark2007UrbanHistory34-Inci?sequence=1. Accessed on: 28 Feb. 2017.

[6] Periathamby, A., Shahul Hamid, F. \& Khidzir, K., Evolution of solid waste management in Malaysia: Impacts and implications of the solid waste bill, 2007. $J$. Mater. Cycles Waste Manag., 11, pp. 96-103, 2009. http://repository.um.edu.my/ 74989/1/solid_waste_bill[3].pdf. Accessed on: 22 Feb. 2016.

[7] Periathamby, $\bar{A}$., Landfilling in developing countries. Waste Manag. Res., 31(1), pp. 1-2, 2013. www.ncbi.nlm.nih.gov/pubmed/23255612. Accessed on: 5 Jan. 2016. 
[8] Van Meter, P. \& Garner, J., The promise and practice of learner-generated drawing: Literature review and synthesis. Educ. Psychol. Rev., 17(4), pp. 285-325, 2005. https://search.proquest.com/docview/758482193?pq-origsite=gscholar.

[9] Dolan, F.E., Ashes and "the Archive": The London Fire of 1666, partisanship, and proof. J. Mediev. Early Mod. Stud., 31(2), pp. 379-408, 2001. $\mathrm{http}: / /$ search.proquest.com/docview/216758345?accountid=15533.

[10] Turchin, P., Dynamical feecbacks between population growth and sociopolitical instability in agrarian states. Struct. Dyn., 1(1), 2005. http://escholarship.org/uc/item/ 0d17g8g9. Accessed on: 23 Feb. 2017.

[11] Jefferies, J., The UK population: past, present and future. Focus on People and Migration, 2005. http://link.springer.com/chapter/10.1007/978-1-349-75096-2_1. Accessed on: 23 Feb. 2017.

[12] The National Archives, The Great Plague 1665-1666: How did London respond to it? www.nationalarchives.gov.uk/documents/education/plague.pdf. Accessed on: 10 Oct. 2017.

[13] Hicks, J. \& Allen, G., Research Paper 99/111 A Century of Change: Trends in UK statistics since 1900. House of Commons Library, 1999.

http://researchbriefings.parliament.uk/ResearchBriefing/Summary/RP99-

111\#fullreport. Accessed on: 23 Feb. 2017.

[14] Johnson, D.G., Population, food, and knowledge. Am. Econ. Rev., 90(1), pp. 1-14, 2000. www.jstor.org/stable/pdf/117278.pdf. Accessed on: 23 Feb. 2017.

[15] Kershaw, I., The great famine and agrarian crisis in England 1315-1322. Past Present, 59(1), pp. 3-50, 1973.

[16] The National Archives, The Great Fire of London.

http://nationalarchives.gov.uk/documents/education/fire-of-london.pdf. Accessed on: 12 Apr. 2017.

[17] Mokyr, J., Entrepreneurship and the Industrial Revolution in Britain. Entrepreneurship in History Conference, eds W.J. Baumol, D.S. Landes \& J. Mokyr, New York: Princeton University Press, pp. 1-45, 2008.

http://citeseerx.ist.psu.edu/viewdoc/download?doi=10.1.1.603.2035\&rep=rep1\&type =pdf. Accessed on: 9 Feb. 2017.

[18] Velis, C.A., Wilson, D.C. \& Cheeseman, C.R., 19th century London dust-yards: A case study in closed-loop resource efficiency. Waste Manag., 29, pp. 1282-1290, 2009. www.researchgate.net/profile/CR_Cheeseman/publication/23719288_19th century_London_dust-yards_A_case_study_in_closed-loop_resource_efficiency/ links/00b7d52cae10174f02000000.pdf. Accessed on: 28 Feb. 2017.

[19] Bingham, P., Verlander, N.Q. \& Cheal, M.J., John Snow, William Farr and the 1849 outbreak of cholera that affected London: A reworking of the data highlights the importance of the water supply. J. R. Inst. Public Heal., 118, pp. 387-394, 2004. http://citeseerx.ist.psu.edu/viewdoc/download?doi=10.1.1.205.9087\&rep=rep1\&type $=$ pdf. Accessed on: 5 Jun. 2016.

[20] Agnoletti, M., \& Serneri, S.N., The Basic Environmental History. Vol. 4, Environmental History, Springer International Publishing: Florence, pp. 1-268, 2014.

[21] Hamlin, C., Chadwick, E. \& The Engineers, 1842-1854: Systems and antisystems in the pipe-and-brick sewers war. Technol. Cult., 33(4), pp. 680-709, 1992. http://s3.amazonaws.com/academia.edu.documents/46572162/hamlin_chadwick_eng ineers.pdf?AWSAccessKeyId=AKIAIWOWYYGZ2Y53UL3A\&Expires=14961366 82\&Signature $=$ Kn3uu7fCAIyQex3bYc6dzS6I7Fo\%3D\&response-contentdisposition $=$ inline $\% 3 \mathrm{~B}$ filename\%3DEdwin_Chadwick_and_the_. 
[22] Geels, F.W., The hygienic transition from cesspools to sewer systems (1840-1930): The dynamics of regime transformation. Res. Policy, 35, pp. 1069-1082, 2006. www.research.manchester.ac.uk/portal/files/22243141/POST-PEER-REVIEWPUBLISHERS.PDF. Accessed on: 22 Feb. 2017.

[23] Kaika, M., Interrogating the geographies of the familiar: Domesticating nature and constructing the autonomy of the modern home. Int. J. Urban Reg. Res., 28(2), pp. 265-286, 2004. www.research.manchester.ac.uk/portal/files/23091674/POST-PEERREVIEW-PUBLISHERS.PDF. Accessed on: 30 May 2017.

[24] Goddard, N., "A mine of wealth"? The Victorians and the agricultural value of sewage. J. Hist. Geogr., 22(3), pp. 274-290, 1996.

http://ac.els-cdn.com/S0305748896900171/1-s2.0-S0305748896900171-main.pdf? tid=3c8d19ac-fe70-11e6-99b2-00000aab0f27\&acdnat=1488367048 2ab344cb86a3b829140800e2cd431c9. Accessed on: 1 Mar. 2017.

[25] Cooper, T., Burying the "refuse revolution": The rise of controlled tipping in Britain, 1920-1960. Environ. Plan A, 42, pp. 1033-1048, 2010. http://journals.sagepub.com/doi/pdf/10.1068/a42120. Accessed on: 28 Feb. 2017.

[26] Environment Agency (EA), Historic Landfill. Open data: Historic Landfill, 2016. https://ata.gov.uk/dataset/17edf94f-6de3-4034-b66b-004ebd0dd010/ historic-landfill. Accessed on: 20 Nov. 2016.

[27] Clark, J.F.M., The burning issue: Historical reflections on municipal waste incineration. AHRB Research Centre for Environmental History, Universities of Stirling and St Andrews, 2003. www.stir.ac.uk/media/wwwstiracuk/cehp/images/ burning-issue.pdf. Accessed on: 14 May 2017.

[28] Louis, G.E., A historical context of municipal solid waste management in the United States. Waste Manag. Res., 22, pp. 306-322, 2004.

http://journals.sagepub.com/doi/pdf/10.1177/0734242X04045425. Accessed on: 12 Jan. 2016. 